MedieKultur | Journal of media and communication research | ISSN 1901-9726

Article

\title{
Genre in media production
}

\section{Hanne Bruun}

MedieKultur 2011, 51, 22-39

Published by SMID | Society of Media researchers In Denmark | www.smid.dk The online version of this text can be found open access at www.mediekultur.dk

How do we explain changes in media genres? Are they the result of economic, technological or other kinds of structural forces; or are they the result of the change-producing agency of the media producers? And how are changes in media texts connected to contextual conditions for media production on micro-, meso- or macro levels? This article suggests that a theoretical approach using a pragmatic and socio-cognitive understanding of genre will help us to address these questions. This approach can highlight the interplay between human agency and different kinds of structural forces involved in specific professional media production cultures. Furthermore, it has the potential to integrate media texts and especially the micro- and meso levels of production. Using lessons learned and findings from my recent production study of Danish television satire, the article will argue three major methodological as well as knowledge-producing advantages of a genre approach.

\section{Introduction}

Addressing the topic of genre in media production studies faces at least two main obstacles. First of all, production analysis is a minor player in media studies compared to other disciplines like textual analysis and audience studies (Frandsen, 2000, 2007). Furthermore, most of the work done has focused on researching news production in different media and 
across platforms (e.g., Schultz, 2006; Domingo \& Paterson, 2008). Nevertheless, in recent years this narrow interest in terms of genre has slowly changed. A broader interest in the production of different media genres is developing, and this is connected with the interest directed at the produsage phenomenon among media researchers (e.g., Bruns, 2008; Jenkins, 2006). The second obstacle is that genre approaches are mainly used in studies of media texts and in studies of the audiences making sense of the media output. The production side of the media is rarely studied using genre as an explicit approach, even though some studies have a very strong implicit use of a genre framing when researching media production cultures (e.g., Caldwell, 2008; Dornfeld, 1998). In this article, I will suggest that a theoretical approach using a pragmatic and socio-cognitive understanding of genre has three major methodological and analytical advantages in media production analysis. The advantages are connected to the fundamental ambition in media studies to integrate texts and contexts of different kinds into the analysis. I will draw on lessons learned and examples from a recent study examining changes to Danish television satire, focusing on the changes in the production culture at The Danish Broadcasting Corporation, DR. DR has been the major player in programming history, in Denmark, going back to 1968 with its offering of television satire as part of its public service entertainment profile, as well as in the changes to the genre since 1999. To illustrate these advantages, I will underline the messiness of genre as well as the pervasiveness of genre in the media as such and in television in particular. This makes genre a difficult phenomenon to analyse but at the same time an indispensable and fruitful tool in researching cultural production.

\section{The drive for an integrating approach}

As the introduction to this volume of MedieKultur argues, the question of genre has been made topical because of the technological changes to the communication media as well as the huge impact of the Internet on the media landscape and its development. This has influenced the analytical object: the media texts, and how these texts are being produced and consumed. A similar interest in genre among media researchers appeared 20-25 years ago. This happened at a time when the deregulation of many European television systems took place and when the new distribution of television across national borders by satellite fundamentally changed the availability of television. Growing competition for audiences changed the European television industry and it changed the content and forms of television. These changes to the sheer volume of media output and also to the speed of changes to the output made researchers take up the question of genre to understand what was going on in television. The British researcher Steve Neale's seminal publications on genre and film (Neale, 1980) inspired a great deal of genre studies on factual television genres, on television journalism and documentary, and they still do. In Danish media research, marked by its strong roots in the humanities, the interest in genre produced research into the changing nature of, for instance, factual television (e.g., Harms Larsen, 1990), of televi- 
sion news (Hjarvard, 1995), talk shows (Bruun, 1999) and television fiction (e.g., Bondebjerg, 1993). The issue of genre was often accompanied by questions of quality and high and low culture, often referring to the work of the American television fiction researchers Thomas Schatz (1981) and Newcomb and Hirsh (1984). In 1990, volume number 14 of MedieKultur was focused entirely on genre, and in 1994, Michael Bruun Andersen wrote a still very important and useful article called 'TV and Genre', mapping the discussions at the time.

The quantity of media output offered and the speed of change to media output is again making genre topical to media researchers, perhaps in an even more radical way than the last time. But why this preoccupation with genre in media studies in the first place? It is probably connected to a basic drive in media studies to be a scientific field in general. Historically and presently, media studies is characterised by the drive to incorporate the three components of the communication model, i.e., sender, text and receiver, into the analysis, as well as the drive to integrate into the analysis texts and contexts of different kinds. One of the ways this ambition has been implemented has been by using an explicit genre approach. Examples of this can be found in audience studies (e.g., Höijer, 1991, 1996; Bruun, 2004) and in production studies (e.g., Nielsen, 1992; Ytreberg, 1999; Grindstaff, 2002; Jensen, 2008, 2009; Kjus 2009). An explicit genre approach has also recently been suggested in the analysis of the Internet and the produsage phenomenon (Giltrow \& Stein, 2009; Lomborg, 2009).

\section{Genre - the pragmatic approach}

Presently, there seems to be a predominant position in the overall understanding of genre, not as widely diffused as the last time genre was in fashion. In line with Todorov's understanding of genre $(1989,1990)$ and in line with the philosophy of language-approach to genre suggested by Bakhtin (1952/1986), there is a common focus on genre as language use/parole. Genre is a phenomenon connected to the conventional aspects as well as the dynamics of language use. The conventional aspects of genres in this theoretical perspective are provisional and of a historical nature, constantly in the loop of being constituted, reproduced in different variations and reshuffled (Neale, 1999, p. 12), which again is producing new conventional aspects. This understanding of genre is based on a pragmatic understanding of what fundamentally characterises human meaning production in everyday life and in professional contexts, in which genre also plays an important role. Genres can be compared to the way social norms work by structuring human communication and social expectations in specific situations, but changeable through the change-producing power of human agency. Furthermore, the approach is based on an understanding that genres have to be analysed in specific historical and contextual circumstances. In short, they are social and historical phenomena.

Positioning genre within the realm of language use and within a pragmatic perspective on the norms and conventions of language use makes genre a very messy thing, but nevertheless extremely important in communication processes. This is the way Neale and the 
many media researchers drawing on his seminal work understand genre. As a consequence, the empirical frame of reference is the function of genre and the question of what genre does in communicative processes between senders, receivers and textual phenomena. This understanding of genre also recognises that it is possible to use genre labels in many different ways adding to the messiness of the term. Labels are based on experiences of similarities between groups of texts typically based on theme, semantics, composition, mode of address and use. Nevertheless, there are three problems to this truism. Firstly, the criteria of defining a genre as a group of texts with similarities can be changed, for instance semantic criteria can be used, or target group criteria etc. can be used. This means that a text can belong to many different genres at the same time. Secondly, the level of definition can be changed. Macro-categories grouping a corpus of texts like entertainment, television fiction or social media can be used as the categorisation tool. But micro-categories of components 'inside' a single text can also be used, for instance epic, didactic and dramatic parts of a text or micro-categories like entertainment and information in a text. This also means that a text can belong to many different genres at the same time. Thirdly, genre is used to cover aspects regarding texts as well as phenomena outside of the text.

Genre involves expectations held by media users and thus in the interpretation processes of texts, and genre also involves production and distribution categories as well as commercial categories used by the producers of media and the media industry. In short, a strong hermeneutic dimension is to be included in understanding what genre does in communication processes.

All of this makes genre a complex phenomenon not easy to handle. However, for exactly the same reason, genre is an important analytical and methodological concept to use in empirical research into media production.

\section{Media texts and contexts}

In production studies, a more media-centric approach has emerged during the last decade, adding new perspectives to the many socio-centric studies dominating the field (Bruun, 2010a). From different perspectives and applying different methodological designs these studies are characterised by focusing on the phenomena being produced, hence the term media-centric. The research interest is focused on form (Cottle, 2004; Scannell, 2004), performance (e.g., Ytreberg, 2010), genre and aesthetics (e.g., Ytreberg, 1999; Born, 2000; Kjus, 2009; Caldwell, 2008; Bruun, 2010b). This media-centric approach is part of an ambition in production studies to find an approach to media texts and media production with an integrating ability able to answer questions about why changes in the media output happen. It is also driven by an interest in understanding the kinds of forces and processes involved in these changes.

A pragmatic genre approach is fruitful as an integrating tool, because it can bypass two classic dichotomies in more socio-centric driven media production analyses. Firstly is the 
question of what is driving change. Is it systemic forces, for instance, technology, economy and competition, or is it the change producing forces of human agency, for instance, creativity, artistic vision and imagination (Frandsen, 2007)? The second classic problem, or dichotomy, is that research either gets focused on texts or contexts, but has difficulties in understanding the connection between the two (Ytreberg, 2000). The pragmatic approach to genre is able to bridge texts and contexts as well as take into account systemic forces and forces of human agency in understanding changes to media output. But the sociological orientation needs to be enhanced. This is needed, because within media studies the pragmatic approach to genre is predominantly a text theory occupied with different kinds of text and textual developments (Mittell, 2001). It is to a much lesser degree a sociological and cognitive theory of genre as a kind of knowledge structuring actions on an individual and social level. If the aim indeed is to understand what genre does in empirical communication processes, a stronger focus on human meaning making is needed.

For a number of years, a cognitive approach to understand the connection between audiovisual fiction and emotional processes in the human brain has been argued in film theory (e.g., Bordwell, 1985; Grodal, 1997). Following this perspective, genre knowledge can be said to have a kind of existence in the human brain and body. Furthermore, an interest in the sociological dimension of genre as a kind of knowledge held by media users and producers can be found in audience studies and text production studies. In socio-cognitive audience research, important theoretical inspiration comes from cognitive psychology and schema theory linked to contemporary brain research in the natural sciences (Shore, 1996; Höijer \& Werner, 1998). Genres, understood as schemata, are frameworks for interpreting and organising experiences, expectations and understandings. These genre schemata are not recipes, however, but are seen as a sort of frame of reference built by the individual using media products, and used in making sense of new experiences and in reshuffling existing and building new genre schemata. In this approach, the genre schema involves the trans-cultural biological conditions of the human brain as well as psychological, sociological and cultural conditions all presumed to influence the production of meaning. Empirical research inspired by this theoretical approach shows that genre schemata do exist as a kind of knowledge held by different audiences, and similarities in genre schemata are found among audiences sharing the same demographics, social and national backgrounds (Höijer, 1991, 1996; Bruun 2004).

However, as Shore argues (1998, p. 7), the schema theoretical approach has the potential to be equally fruitful in media production research. A socio-cognitive perspective on genre used in the analysis of professional text production cultures is convincingly argued for instance by Berkenkotter and Huckin (1993). Drawing on a re-conceptualised rhetorical view on genre from a sociological perspective (Miller, 1984), and drawing on philosophy of language and ethnomethodology in the analysis of academic text production, the results point to the benefits of using this approach also when analysing professional media production cultures. Berkenkotter and Huckin strongly emphasise that, in a production 
context, genre is to be regarded as a kind of knowledge held by and used creatively by the participants of a specific production culture (ibid., p. 485). All in all, a stronger sociological orientation is added to the integrating perspective of genre in media production analysis.

But why is this enhancement important? There are three major reasons. Firstly, production of television and the majority of professional media production take place in institutional or organisational contexts as well as in an industrial context marked by economic, political and technological aspects on different levels. Individuals work together in these specific contexts producing different kinds of texts. As suggested by Frandsen (2007), these texts, even if collectively produced, are in very different ways dependent on the creative power of human agency. For instance, television drama production compared to production of quiz shows is extremely dependent on the skills of the script-writer(s). Secondly, the enhancement is important because the agents in these institutions are trained professional media producers with expert knowledge, and with power over the actual products being produced, distributed and sold. And thirdly, we are dealing with text producing practises performed by professionals. These practises can be hard to put into words by the professionals because they are part of professional training processes. Sometimes they are only visible in actual actions and part of what Polanyi calls the 'tacit dimension' of knowledge (Polanyi, 1967); the 'We can know more than we can tell' kind of knowledge.

\section{The production of satire study}

As a production category, satirical sketch comedy is an entertainment genre deeply dependent on the creative and interpretative abilities of media professionals, shorthand for controllers, producers, editors, writers, performers etc. Their aim is to offer the viewers a critical, comprehensible and, most importantly, funny diagnosis of a presumably shared political and cultural reality. However, seen from a text-analytical point of view, a transformation of quantity, content and form took place within the programming tradition in Danish public service television during the first decennium of the 21st century (Bruun, 2011). To illustrate the quantitative change, the two public service television providers in Denmark - DR and TV2 - scheduled 68 programmes in the period from 1991-95, and 340 programmes in the period from 2001-05. These were all scheduled on two niche channels: DR2 and TV2/Zulu. Even if satire was still a pygmy among the different television entertainment genres in terms of broadcasting time, the amount of time spent on satire in prime time rose from $0.1 \%$ in the period from $1989-93$ to $0.4 \%$ in the period from $2005-09$.

In terms of content, the programmes incorporated the satirical treatment of not only political, but also social and lifestyle aspects of modern life in the Danish society. Political satire mirroring the news-agenda of the week and characterised by attacking the arrogance and hypocrisy of politicians and other powerful agents in society used to dominate the genre from 1968 until the late 1990s. Nevertheless, series characterised by social satire came to dominate over political satire in the following 10 years. These series were characterised 
by portraying individuals from different social groups in the Danish society and the way cultural trends and social demands affected the behaviour, norms and self-image of the individual. These programmes cultivated loss of face as their driving comedic force. This development meant that the viewers were presumed to be knowledgeable about political issues as well as the stereotypes, mentalities and narratives in the society in which they lived. The viewers were also supposed to know the social 'dos and don'ts', and to know the normative frameworks of the socio-political and cultural realities in which they lived. The viewers were addressed as everyday sociologists and citizens, and because of social satire's dominant position, political knowledge picked up from the news media on an everyday basis was becoming less important for generating the entertainment value.

In terms of form, many different media genres and aesthetic conventions of various media discourses were put to use as the aesthetic vehicles of the satire, as well as being the objects of satire in themselves. Parody and pastiche, in particular, were increasingly important, and media satire was therefore a prominent outcome of Danish television satire. The programmes were sometimes even multi-platform formats involving the Internet as well as television, and the media satirical edge was directed at established Internet genres as well (Bruun, 2007). All in all, the producers presumed the viewers to be experienced media users, and the viewers were addressed as media-cultural literates, so to speak, who were able to understand and detect genre clues and mistakes intuitively and quickly, in order to understand the entertaining qualities of the satirical treatment.

The qualitative changes to the sketch comedy satire programmes during the period were accompanied by changes to the strategic use of the genre. The programmes were moved from being scheduled on the mainstream channels as part of a Saturday-night entertainment profile aimed at a mainstream audiences, to being scheduled on niche channels provided by the public service broadcasters. Furthermore, the programmes were targeted at the young and young adults (Bruun, 2007). In short, satirical sketch comedy became a tool in the growing competition for specific audiences. Consequently, the genre played an important role in the transformation of the public service providers. These providers were and are still trying to survive in the new era by redefining their obligations as providers of public service media on different platforms, rather than as broadcasters of public service programming on television and radio. Public service providers are struggling to position themselves and legitimise themselves in relation to audiences, politicians and other competing media institutions on the market.

However, the questions still remain regarding how the actual approaches to producing satirical sketch comedy have changed. For this reason, the objective of the production study was to shed some light on the changes in the production culture of this specific field of production, and to understand the driving forces in its development. In line with Caldwell (2008), my goal was to understand the value-based and professional experience- and knowledge-based work being done, which resulted in the actual programmes. Controllers, commissioning editors, executive producers, programme editors, writers and directors were 
making these described changes happen in the body of programmes and in the scheduling. As a point of departure in this study, these changes were regarded as genre interpretations made in this specific 'biotope' of television production (Jensen, 1984). They were regarded as interpretations involving the growing media competition for specific audiences, technological as well as organisational and media policy changes, affecting the way this particular television genre and programming tradition were perceived and produced (Born, 2000). All these factors were believed to influence the ideological orientations of the producers, in terms of what was identified as satire and believed to be the purpose of it, as well as being in line with the needs of the imagined viewers, the broadcaster, the production company etc.

The basic design of the study was a diachronic analysis (Jensen, 1984, p. 105; Ytreberg, 2000) focusing on the production of political satire and social satire at DR that are the major contributors to the genre tradition and to the above-mentioned changes. Two typical cases were chosen. The first case was the production of TV-Ansjosen DR1, 1995-98, and the last satirical sketch comedy series produced for the Saturday night prime time schedule and for a main stream audience. The second case was the series Drengene fra Angora, 2004, produced for the up-market niche channel DR2. From 2003 until 2009, DR2 scheduled satire during Friday night prime time. Drengene fra Angora is still the biggest satire hit DR2 has had in terms of ratings, and like the rest of the productions for DR2, since 1999 the series attracted especially young adults (20-30 year olds). Because of the goal to understand why genre changes happen over a long period of time, the interview was a very important datagathering tool in the study. I interviewed 14 people involved in the two productions, one or more times during 2008 and 2009. They were all people with direct creative or managerial power, from channel controllers and program editors to writers and performers. There are three major advantages of applying a genre approach in this study. These are connected to the methodological design of the study as well as to the production of findings.

\section{Advantage no. 1: Knowledge producing integration}

A genre approach is able to integrate the texts produced in the methodological design of a media production study. This is very helpful, and I will return to elaborate on the reason for this advantage below. However, it is important to acknowledge that a genre approach is not just a methodological tool. It has an integrating perspective that is producing knowledge as well, and therefore is not just a tool.

\section{Methodological advantages}

The approach has a very big say in getting access to construct an analytical object. Getting access is no doubt the biggest obstacle to production studies. The media are professional organisations and businesses and part of the social sphere. They form a competitive system between private commercial businesses or a dual system of commercial and public service organisations. As a rule, researchers do not have access to do research within these organi- 
sations, but are hopefully given access either as a gift or as a trade of services between the researcher and the media organisation (Frandsen, 2007; Bruun, 2011). In short, somebody has to be interested in helping the researcher. To solve this problem it is very productive to take the products produced by these professionals as the point of departure. The researcher can then ask for help to understand why the products turns out as they do. This approach entails a high degree of compatibility. It positions the interviewees as professional individuals with power, and not just as 'puppets on a string'. This is also compatible with their own self-image, not different from other professionals working in the creative industries (Deuze, 2007; Hesmondhalgh \& Baker, 2010). Furthermore, a genre approach is also compatible with the way these professionals think of their own profession and what could be called their professional knowledge: television producers think and talk in terms of genre, genre differences and audiences for different genres. They think and talk in terms of professional and creative competences connected to genres as well. And finally, taking this into account makes the researcher seem as an almost sensible person to help.

The preoccupation with genre in television production is really not surprising and very much a result of the pervasive use of genre in the media industries, especially in the television industry. This might seem trivial and easy to take for granted, nevertheless important to take into account. First of all, the textual phenomena, e.g., channels, websites or programmes, are labelled and scheduled according to genres able to attract the right audience in order to meet strategic goals. Secondly, the media organisations as physical organisations are structured according to the production of genres, for instance divisions or departments of news, fiction, entertainment, lifestyle etc. Furthermore, these organisations are staffed to facilitate the production of specific genres, for instance commissioning editors, programme editor etc. of entertainment, satire and documentaries. And finally, in dealing with in-house and out-sourced productions, genres are very important categorisation tools.

Thirdly, the political regulation and legal control systems of the media and indeed television on a national and international level are also using genres, for instance, when formulating remits for public service media, and regulating the conditions for commercial media. Finally, the television industry as an international business is very much a trade where the products are organised in different genre categories, for instance, the international trade with programmes and formats at MIPCom and international fairs and festivals. The production companies used by the broadcasters are often specialised in the production of specific genres, and the knowledge regarding the kind of theory generated by the television industry itself is based on genres, for instance, reports on quality and 'how-do-to - $X$ '-books and production guidelines are taking genres as a point of departure.

In gathering data, the genre approach gives the researcher an opportunity to use the actual programmes and the corpus of texts produced actively. This has played an important role in my study, and the catalogue I produced can serve as one example of how the texts were used: I produced a comprehensive catalogue of all in-house produced satirical sketch comedies on DR, DR2, TV2 and Zulu from 1968 to 2009. It also contained viewer 
figures from 1988 to 2009. This catalogue was used to inform the interviewees before the interviews and during the interviews. It turned out to be a very productive tool: it produced a factual reference for talking about productions and their popularity in terms of ratings and shares and it helped memory along by grounding it in descriptions of specific productions and processes and not just opinions. It produced $a$ sense of the cultural contributions made by the professional interviewees over a long period of time and they all really liked browsing through it. Finally, it validated my work, because the interviewees added productions to the catalogue that I had failed to notice or take into account, and thereby it informed my genre categorisation.

\section{Production of findings}

Apart from these methodological advantages, the integrating abilities of the genre approach also produce findings. First of all, the television satire-study supports the theoretical argument that producing media products involves interpretation of a pre-existing genre tradition as a corpus of texts within a specific television organisation and within a specific historical context. Secondly, this entails communicative intentionality regarding the communicative purpose of the genre, its role in the schedule and its intended audience. For the producers of social satire, for instance, the programming tradition of satirical sketch comedy and the inheritance from the political branch within the tradition played an important role. Production as interpretation is present in the way one of the three writer-performers of Drengene fra Angora, Rune Tolsgaard, describes the intentions behind the production:

It is a specific format in itself to do a 30-minute satire programme. We also wanted it to have the feeling of Saturday-night entertainment, but with an edge and with a bite. We really embraced the tradition way back from Buster Larsen and we were not afraid to dress up in a big way. (...) We are often asked why we do not do political satire. But it is too crude; like spelling it all out. I find it much more sophisticated if the people have to figure out for themselves why something is funny. (Writer-actor Rune Tolsgaard, interviewed 18.3.2009)

In this quote, the series is positioned as part of a programming tradition of 30-minute satirical sketch comedy shows (the 'format') reaching back to 1968. The programmes for 30 years were scheduled as primetime Saturday night entertainment, but with a specific and recognisable communicative intentionality: fun with an edge. According to Tolsgaard, the big differences between the traditional and what are seen as the characteristics of Drengene fra Angora as a new 'family member' is the kind of satirical comedy intended and the way it is constructed. All in all, the results of the study really support Joli Jensen's suggestion that cultural production is to be regarded as interpretation, and therefore production research needs to combine theoretical approaches from both sociology and the humanities (Jensen, 1984). Using a genre approach is one fruitful way to do this.

Furthermore, the notion that genre is part of conventionalised yet dynamic language use in a specific context is also supported very strongly. An example taken from the study 
is the way the producers of political and social satire, respectively, understand the critical purpose of producing satirical sketch comedy. In the following two quotes, the programme editors formulate what they regard as one of the core values of satire. The first quote is from my interview with the programme editor and writer of Tv-Ansjosen, as well as many other series at DR during the 1980s and 1990s, Claus Flygare:

The goal is, after all, to produce satirical texts. Ideally, your criticism should target those who have the power and all the money, and the influence as well. That is the purpose of satire! We also pissed on all the holy cows. The aim was to open people's eyes, but never to pull in any specific political direction. (Programme editor and writer Claus Flygare, interviewed 29.3.2008)

The second quote is from my interview with the programme editor and director of Drengene fra Angora, and other series at DR2 during the 2000, Jesper Rofelt:

It [the goal] is the humiliation of the characters. There is a lot of stuff in the series that could be regarded as downright cruel and vicious. But it pokes at you as well, and that is because what happens is also very familiar. And it is a satirical programme too and you are supposed to laugh. Nevertheless, it has to be familiar as well, and this familiarity has to stick with you. (Programme editor and director Jesper Rofelt, interviewed 27.2.2009)

Both of the interviewees are talking about the purpose of producing the same format: satirical sketch comedy. But the aim of the critique in social satire has undergone an almost paradigmatic change compared to that of political satire. It has changed from a critique directed at the political and economically powerful in a democratic society to a critique based on loss of face and directed at familiar social stereotypes.

Another example from the study that also points to the duality of genre in a professional production culture is how an understanding of the intended audience structuring the production is formulated. This is also reflecting an organisational context in two very different historical periods of Danish television. The first quote is from my interview with former head of the entertainment department at DR, Henrik Woldgaard-Iversen. Before he became head, he was programme editor of many series in the 1970 s.

What I imagined was the general audience. For that reason it had to be popular in style. We made one big marzipan bar mixed with a couple of bitter almonds. That was the intention. But it wasn't something you gave much thought. It was part of the subconscious. That was what it was all about. We are talking about a mass medium, and satire was costly. It had to reach the masses. That was the idea! (Former head of entertainment and editor of satire Henrik Wolsgaard-Iversen, interviewed 7.3.2008)

In comparison, the second quote is again from the interview with Jesper Rofelt, formulating the intended audience in this way: 
We had a clear ambition with this series. We wanted to do a series that WE would bother to watch ourselves. It had to be funny in a way that WE liked. Perhaps it was mentioned in some notes that the series was intended for 15- to 25-year-olds. But the important thing was that WE had this good feeling about the series. It was like a band, jamming in the rehearsal room, and suddenly everything comes together, and makes perfect sense. (Programme editor and director Jesper Rofelt, interviewed 27.3.2009)

The kind of comedy and the intended audience as well as the imagined communicative relationship between the producers and the audience have undergone big changes, again almost paradigmatic. It has changed from a didactic ambition and an awareness of the producers being different from the audience, to ambitions centred on self-expression where the audience has almost imploded. The audience is in fact the producers themselves. However, both talk about the same genre: the satirical sketch comedy show!

To sum up this first advantage of knowledge production, using a genre approach supports a double role of the interviewees pointed out by Kvale (1994): They serve as informants as well as representatives of the values and "belief systems" (Caldwell, 2008) of the production culture that has undergone important changes in its understanding of the purpose of producing a specific kind of content and the intended audience.

\section{Advantage no. 2: Texts cum contexts}

The second major advantage of a genre approach is its ability to highlight the interaction between the cultural products: the texts, and the organisational and industrial contexts. In fact, the texts are interwoven with contextual factors in such a way that it is rather difficult to draw a line between the two. An example from the study is about one of the important reasons why social satire came to dominate the satirical sketch comedy after 1999. The way DR produced satire did not change from 1968 to 1999, and the production model used gave priority to topicality mirroring the news agenda of the week, and it was extremely expensive (Bruun, 2010b). In my interview with the former head of the entertainment department Henrik Wolsgaard-Iversen, he described the normative status of the genre and its economic conditions within DR in the period as "a flagship in a golden coach". The costs were at the level of news production and fiction, and with a very limited turn out of programmes that were not fit for reruns either. In short, a lot of resources were spent on producing very few programmes, approximately 1-2 series of 3-6 episodes a year.

Furthermore, after 1988 when daily ratings informed the broadcasters, these expensive and high profiled programmes turned out to generate relatively low ratings. DR's declining market share during the beginning of the 1990s and the launch of the up-market niche channel DR2 to stop this decline influenced DR as a whole. But in the production culture of satire, it made the conventionalised way of producing satire change radically. The need for entertainment programmes with a high status inside and outside of DR to fill the schedule made the management move satirical sketch comedy to DR2. But because the traditional 
way of producing satire was no longer affordable, this move had a huge impact on what was produced and labelled as satire.

As a result, from 1999 and onwards, DR2 commissioned what was regarded as lowbudget productions from freelance ensembles of young mostly unknown comedians, often produced by external production companies. These productions had a high re-circulation value because the majority of these series did not mirror the news agenda of the week, and became usable material on new platforms: DR's Internet site for satire and on YouTube, Face Book etc. All in all, this meant a huge increase in the production of satire: 4-6 series a year with 12-70 episodes each.

As this brief example hopefully illustrates, a genre approach to media production paves the way for understanding the concrete interaction between micro- and meso level factors and the products produced. Factors like, for instance, the normative status of a genre, the models for recruitment of new talent within specific production cultures as well as the distribution of editorial and economic power within the media organisation are part of the products produced. Furthermore, factors like the strategic use of certain genres by the media company in order to for instance fulfil the public service remit and to move public service to new platforms influence the products. Finally and very importantly, economics influence the products in a very concrete way. All in all, this multitude of concurrent contextual factors that Syvertsen (1997) calls the business logics and structural factors of the television business must be taken into account in the effort to understand changes to the media products.

\section{Advantage no. 3: Professional genre knowledge}

A third major advantage of a genre approach in production analysis is that it provides an empirical access to the professional genre knowledge involved in the different fields or 'biotopes' of media production. I have already touched upon this advantage in connection with the methodological advantages described, but I would like to add more to this regarding the different kinds of professional knowledge a genre approach is able to elicit.

In television production, I would suggest that professional genre knowledge is embedded in specific conventionalised practises within a larger media production environment. A genre approach is able to frame verbal narratives, actions and practises, and by so doing it is able to gain insight into the tacit dimension of media production; that is gain insight into the conventionalised professional genre knowledge that is sometimes hard to put into words.

An example from the satire-study is the way topicality was taken for granted and described as a core value in what counted as satire. This value structured the production model, the creative work and the quality assessments in the production culture. One of the five writers for TV-Ansjosen, Annegrethe Kraul, describes the influence this core value had on her and the other writers' work: 
We had to make sure that there was topicality. You were not supposed to just write something... we were supposed to be mirroring the news week. We always made sure that at least one of the sketches was referring to a story told in the television newscast the same day. (Writer Annegrethe Kraul, interviewed 24.4.2008)

In other words, in the production culture of political satire, reference to actual and specific events and individuals in the world already in the news circuit of the past week was a constitutive element. Without this reference there was no satire, just comedy.

I would also suggest that professional genre knowledge structures specific commissioning criteria within a larger commissioning system; criteria that can be more or less explicit. An example from my study is that when the production model used from 1968 to 1998 was no longer affordable and DR opened up for other comedians and production companies to do satire, the commissioning editors were flooded with suggestions and pitches. The commissioning editor for satire at DR2 from 2003-06 Mikael Bertelsen gradually developed two selection criteria informed by the ratings of the series already produced and by strategic needs for branding DR2 as a channel and as part of the DR-family. In order to gain access to the production culture of satire and the DR2 'brand', the suggested productions had to meet two criteria. Firstly, the suggestion or pitch had to contain an experimental ambition challenging the forms and content of DR2-satire and the television medium. Secondly, it had to contain an artistic and personally embedded need for expression compatible with the DR2-brand. Of course this became self-perpetuating and formed a new set of generic conventions. In short, these criteria constituted the conventions of the production culture and supported the production of social satire.

Finally, I will suggest that professional genre knowledge is embedded in relatively autonomous production cultures within an overarching production system that can be driven by public service obligations or commercial logics, or a mixture of both. Results from the satire study supports that the production culture of satire has cultivated a very specific interplay with a growing comedy scene outside of television in Denmark during the 2000s. This interplay is very different from what other television entertainment genres have managed to do. The interplay has turned into a mainly profitable interdependency between television and the comedy industry in Denmark. The results of the study show that at the moment, among the comedians trying to make a living, television is regarded as the most important stepping stone. In spite of the many benefits of Internet genres like YouTube and Face Book, television is still regarded as the most important mass medium of cultural production. Getting access to produce a television show is regarded as much more important to a successful career than productions in any other medium or on the stage. The relationship between television and these comedians is described in a way that makes it very similar to the one between a pop or a rock band and a record company.

To sum up, this third advantage of a genre approach points to these three major features of the professional genre knowledge intrinsic to a production culture and its development in a specific social and historical context. These insights are very fruitful because they might 
help the researcher to understand the characteristics of media production in specific fields, and to prevent the researcher from making sweeping generalisations from one production culture to another.

\section{Concluding remarks}

In my experience, also as an audience researcher, even if genre is a difficult phenomenon, it is a very valuable concept in researching media text production because is contains an integrating perspective that works methodologically as well as analytically. The approach has the ability to highlight the interplay between human agency and different kinds of structural forces involved in specific professional media production cultures. Furthermore, it has the potential to integrate media texts and especially the micro- and meso levels of production, and by doing so making an empirically grounded contribution to understand why media output change. This empirical grounding may also finally support the macro level of genre analysis. As argued by Mittell (2001, pp. 18-19), the approach enables a cultural politics of genre perspective "situating genre within power relations" (ibid., p. 19).

The benefits or advantages of using genre in media research, and media production research in particular, are far more important than the doubts being raised concerning genre as fruitful in understanding the present media culture. The amount of output and the speed of change are all good reasons for continuing to use the concept. However, in researching the question of genre, the metaphorical use of the term 'communicative contract' when talking about what genre does in the communication process, might be a bit problematic. The associations to legal documents and legally binding agreements between parties are at odds with the described predominant theoretical assumption achieved concerning genre during the past 20-25 years. In using the term contract, we might focus our attention too much on individual textual phenomenon and not the genre confusing the two levels and as a consequence giving very little room for diversity within a specific category. Secondly, by using the term contract we might be overstating the conventional side of genre, and underestimating the dynamics and flexibility of genre as well as the 'elasticity' of a specific genre label. The frequent use of labels like hybrid genre, mash-up and genre mix is perhaps a sign of this problem. Finally, it is important not to paint a picture of an (never existing) empirical past in media studies where there were no problems with categorisations and texts fell neatly into clearly separated boxes.

Within what I would call an interpretation perspective on genre, the focus is very much on the pragmatic usability of genre in the analysis of these communicative processes of producing and using media communication in a changing media world. I would also like to suggest, that the problems with the concept of genre are probably not in the empirical world but in a theoretical and epistemological one; it has to do with the way we understand the empirical world, not the empirical world as such. 


\section{References}

Andersen, M.B. (1994). TV og Genre. In P. Dahlgren (Ed.), Den Mångtydiga Rutan (pp. 207-25). Stockholm: JMK.

Bakhtin, M. M. (1952 [1987)). The Problem of Speech Genres. In C. Emerson \& M. Holquist (Eds.), Speech Genres \& Other Late Essays (pp. 60-102). Austin: University of Texas Press.

Berkenkotter, C. \& Huckin, T.N. (1993). Rethinking Genre from a Sociocognitive Perspective. Written Communication, 10(4), 475-509.

Bondebjerg, I. (1993). Elektroniske fiktioner - TV som fortællende medie. København: Borgen.

Bordwell, D. (1985). Narration in the Fiction Film. London: Methuen

Born, G. (2000). Inside television: television studies and the sociology of culture. Screen, 41(4), 404-424.

Bruns, A. (2008). Blogs, Wikipedia, Second Life, and Beyond. New York: Peter Lang.

Bruun, H. (2004). Daytime talkshows i Danmark. Århus: Modtryk.

Bruun, H. (2007). Satire as Cross-Media Entertainment for Public Service Media. In G.F. Lowe and J. Bardoel (Eds.), From Public Service Broadcasting to Public Service Media (pp. 187-98). Göteborg: Nordicom.

Bruun, H. (2010a). Genre and interpretation in production: a theoretical approach. Media, Culture \& Society, 32(5), 723-737.

Bruun, H. (2010b). Tv-satire. In H. Bruun \& K. Frandsen (Eds.), Underholdende tv (pp. 223-54). Aarhus: Aarhus University Press.

Bruun, H. (2011). Dansk tv-satire. Underholdning med kant. København: Books on Demand.

Caldwell, J.T. (2008). Production Culture. Industrial Reflexivity and Critical Practices in Film and Television. Durham: Duke University Press.

Cottle, S. (2004). Producing Nature(s): On the Changing Production Ecology of Natural History TV. Media, Culture \& Society, 26(1), 81-101.

Deuze, M. (2007). Media Work. Cambridge: Polity Press.

Domingo, D. \& Paterson, C. (2008) (Eds.), Making Online News. New York: Peter Lang.

Dornfeld, B. (1998). Producing Public Television. New Jersey: Princeton University Press.

Frandsen, K. (2000). Forskningen og afsenderleddet. MedieKultur, 3, 110-107.

Frandsen, K. (2007). Produktionsanalyse: teoretiske og metodiske problemstillinger. In H. Bruun and K. Frandsen (Eds.), Tv-produktion - nye vilkår (pp. 23-54). København: Samfundslitteratur.

Giltrow, J. \& Stein, D. (2009). (Eds.), Genres in the Internet: Issues in the theory of genre. Amsterdam \& Philadelphia: John Benjamins Publishing Company.

Grindstaff, L. (1997). Producing Trash, Class, and the Money Shot: A Behind-the-Scenes-Account of Daytime TV Talk Shows. In J. Lull and S. Hineman (Eds.), Media Scandals (pp. 164-202). Oxford: Polity Press.

Grindstaff, L. (2002). The Money Shot: Trash, Class, and the Making of TV Talk Shows. Chicago: University of Chicago Press.

Grodal, T. (1997). Moving Pictures. A New Theory of Film Genres, Feelings, and Cognition. Oxford: Clarendon Press.

Hagen, I. (1998). Creation of Socio-Cultural Meaning. In B. Höijer \& A. Werner (Eds.), Cultural Cognition. New Perspectives in Audience Theory (pp. 59-72). Göteborg: Nordicom.

Hesmondhalgh, D. \& Sarah Baker (2010). Creative Labour: Media Work in Three Cultural Industries. London: Routledge.

Hjarvard, S. (1995). Internationale tv-nyheder. København: Akademisk Forlag.

Höijer, B. \& Werner, A. (1998). (Eds.), Cultural Cognition. New Perspectives in Audience Theory. Göteborg: Nordicom.

Höijer, B. (1991). Lustfylld glömska, kreativ illusion och realitetsprövning. Om publikens tankeprocesser vid tittande på fiction och fakta. Stockholm: Sverige Radio, 15. 
Höijer, B. (1996). Audiences' expectations on the interpretations of different television genres: A socio-cognitive approach. Paper at IAMCR-conference, Sydney.

Jenkins, H. (2006). Convergence Culture. Where Old and New Media Collide. New York: New York University Press.

Jensen, J. (1984). An Interpretive Approach to Culture Production. In W.D. Rowland \& B. Watkins (Eds.), Interpreting Television: Current Research Perspectives (pp. 98-118). London: Sage.

Jensen, P.M. (2008). The International Extent and Elasticity of Lifestyle Television. MedieKultur 45.

Kjus, Y. (2009). Event Media: Television production crossing media bounderies. PhD dissertation. Oslo: University of Oslo.

Kvale, S. (1994). Inter View. København: Hans Reitzels Forlag.

Larsen, P.H. (1990). Faktion som udtryksmiddel. København: Amanda.

Lomborg, S. (2009). Navigating the Blogosphere: Towards a genre-based typology of weblogs. First Monday $14(5)$.

Miller, C.R. (1984). Genre as Social Action. Quarterly Journal of Speech 70(2), 151-167.

Mittell, J. (2001). A Cultural Approach to Television Genre Theory. Cinema Journal 40(3), 3-24.

Neale, S. (1980). Genre. London: British Film Institute.

Neale, S. (1999). Genre and Hollywood. London: Routledge.

Newcomb, H.M. \& Hirsch, P.M. (1984). Television as Cultural Forum: Implications for Research. In W.D.

Rowland \& B. Watkins (Eds.), Interpreting Television: Current Research Perspectives. London: Sage.

Nielsen, P.E. (1992). Bag Hollywoods drømmefabrik. Unpublished PhD dissertation, Århus: University of Aarhus.

Polanyi, M. (1967). The Tacit Dimension. London: Routledge \& Kegan Paul.

Scannell, P. (1994). Kommunikativ intentionalitet. MedieKultur, 22, 30-40.

Scannell, P. (1996). For a Phenomenology of Radio and Television. The Journal of Communication, 45(3), 4-19.

Scannell, P. (2003). The Brains Trust: a historical study of the management of liveness on radio. In S. Cottle (Ed.), Media Organisation and Production (pp. 99-112). London: Sage.

Schatz, T. (1981). Hollywood Genres. Formulas, Filmmaking and the Studio System. New York: Random House.

Schultz, I. (2006). Bag Nyhederne - vardier, idealer og praksis. Frederiksberg: Forlaget Samfundslitteratur.

Shore, B. (1996). Culture in Mind. Cognition, Culture, and the Problem of Meaning. Oxford: Oxford University Press.

Shore, B. (1998). Model Theory. A Framework for Media Studies. In B. Höijer \& A. Werner (Eds.), Cultural Cognition. New Perspectives in Audience Theory. Götebord: Nordicom

Syvertsen, T. (1997). Den store TV-krigen. Norsk allmennfjernsyn 1988-96. Oslo: Fagbokforlaget.

Todorov, T. (1989). Den fantastiske litteratur. København: Klim.

Todorov, T. (1990). Genres in Discourse. Cambridge: Cambridge University Press.

Ytreberg, E. (1999). Allmennkringkastingens autoritet. Endringer i NRK Fjernsynets tekstproduktion 19871994. Oslo: Universitetet i Oslo.

Ytreberg, E. (2000). Notes on Text Production as a Field of Inquiry in Media Studies. Nordicom Review, 21, 53-62.

Ytreberg, E. (2010). The production of mediated performance. In V. Mayer (Ed.), Blackwell's International Companion for Media Studies: Production. Blackwell. 
Article: Genre in media production

Hanne Bruun

Associate Professor, PhD

Department of Aesthetics and Communication,

Section for Information and Media Studies

Aarhus University, Denmark

imvhkb@hum.au.dk 